\title{
PENGARUH LEMBAGA KEUANGAN MIKRO SYARIAH (LKMS) BERKUALITAS TERHADAP PENINGKATAN KEUNTUNGAN USAHA MIKRO KOTA DEPOK
}

\author{
Aditya Hadid Riyadi \\ Mahasiswa Departemen Ekonomi Syariah-Ekonomi dan Manajemen-Institut Pertanian Bogor \\ Email: Aditya_hadid@apps.ipb.ac.id \\ Jaenal Effendi \\ Departemen Ekonomi Syariah- Ekonomi dan Manajemen-Institut Pertanian Bogor \\ Email: Jaenaleffendi@apps.jpb.ac.id \\ Tita Nursyamsiyah \\ Departemen Ekonomi Syariah- Ekonomi dan Manajemen-Institut Pertanian Bogor \\ Email: Titanursyamsiyah@apps.ipb.ac.id
}

\begin{abstract}
:
Micro-enterprises generally have the potential to improve people's living standards and have contributed to economic growth in Indonesia. In its development process, capital is the biggest problem faced by micro enterprises due to the number of microbusinesses that are still unbankable. The existence of alternative financial institutions other than banks that can overcome these problems is needed. Islamic microfinance institution (LKMS) or commonly known as BMT is the best solution to solve the capital problem of micro enterprises. Easy access to financing for microenterprises and mutually beneficial profit sharing system, LKMS has become a solution for the development of member's business. This study aims to analyze the effect of islamic micro financial institution (LKMS) on the increase of profit of microenterprises in Depok City using Ordinary Least Square (OLS) method. The result of research shows that there is a significant influence of the increase of profit of microenterprises after financing in LKMS.
\end{abstract}

Keywords : Financing, LKMS, Microenterprises, OLS

\section{PENDAHULUAN}

Indonesia saat ini menjadi salah satu negara yang tergabung kedalam organisasi G-20 (The Group of Twenty), dengan menjadi bagian negara G-20 menjadikan Indonesia termasuk kedalam 20 Negara dengan ekonomi terkuat di dunia. Hal tersebut tidak terlepas dari keberhasilan Indonesia melewati krisis ekonomi pada tahun 2012 yang dikarenakan mayoritas unit usaha di Indonesia berbentuk Usaha Mikro, kecil dan Menengah yang tidak terpengaruh terhadap krisis global.

Peran UMKM khususnya Usaha Mikro terasa sangat besar dalam membangun dan memajukan perekonomian Indonesia. Usaha Mikro merupakan bentuk ekonomi kerakyatan yang memiliki banyak manfaat seperti: menyerap tenaga kerja, memperbesar pertumbuhan Produk Domestik Bruto (PDB) dan membangun ekonomi nasional. perkembangan UMKM yang ada di Indonesia dari tahun 2016 ke 2017 tercatat peningkatan UMKM di Indonesia sebesar $2.06 \%$ dengan mayoritas terjadi peningkatan di bidang Usaha Menengah dengan presentase $3.56 \%$. Untuk Usaha Mikro sendiri masih menjadi bentuk usaha yang paling banyak dengan pangsa sebesar $98.70 \%$ atau total lebih dari 60 juta Usaha Mikro di Indonesia. 
Riyadi, et al/Jurnal Ekonomi Syariah Teori dan Terapan Vol. 6 No. 5 Mei 2019: 1082-1096; PENGARUH LEMBAGA KEUANGAN MIKRO SYARIAH (LKMS) BERKUALITAS TERHADAP PENINGKATAN KEUNTUNGAN USAHA MIKRO KOTA DEPOK

Tingkat penyerapan tenaga kerja UMKM yang bergerak secara positif, tercatat dari tahun 2016 sampai 2017 peningkatan tenaga kerja yang terserap dari sektor UMKM sebesar $3.41 \%$ dengan peningkatan penyerapan tenaga kerja terbanyak pada bidang Usaha Kecil sebesar $5.60 \%$. Walaupun secara persentase peningkatan tenaga kerja Usaha Mikro hanya meningkat $3.27 \%$, tetapi untuk proporsi penyerapan kerja Usaha Mikro masih menjadi yang terbesar dengan jumlah lebih dari 107 juta tenaga kerja atau mampu menyerap tenaga kerja sebesar $89.17 \%$. Hal ini membuktikan bahwa Usaha Mikro memiliki pengaruh positif dalam menyerap tenaga kerja yang ada di Indonesia.Usaha Mikro juga memiliki pengaruh yang besar terhadap pendapatan PDB di Indonesia. Pada tahun 2017 tercatat PDB Indonesia yang berasal dari Usaha Mikro lebih dari 4 Triliyun rupiah atau meningkat $10.15 \%$ dari tahun sebelumnya, akan tetapi kontribusi PDB Usaha Mikro masih lebih kecil jika dibandingkan dengan kontribusi pendapatan PDB dari Usaha Besar yang memiliki pangsa $42.92 \%$.

Secara umum usaha mikro memiliki potensi untuk menjadi sarana bagi peningkatan taraf hidup masyarakat dan telah memberikan kontribusi terhadap pertumbuhan ekonomi. Hanya saja kondisi di lapangan masih banyak ditemukan permasalahan yang menyebabkan UMKM di beberapa daerah tidak dapat survive. Beberapa di antaranya dikarenakan: (1) pendapatan rendah, (2) kualitas rendah, dan (3) belum siap menghadapi persaingan global, misalnya AEC (Asean Economy Community). Selain itu menurut Beik dan Arsyianti (2015) ada lima masalah yang sering dialami UMKM seperti: (1) terbatasnya modal dan akses dari sumber lembaga keuangan, (2) masih rendahnya kualitas SDM pelaku usaha, (3) kemampuan pemasaran yang terbatas, (4) akses informasi usaha yang rendah dan (5) belum terjalin kemitraan yang baik yang saling menguntungkan antar pelaku usaha UMKM, usaha besar dan Badan Usaha Milik Negara (BUMN) ataupun Badan Usaha Milik Daerah (BUMD). Dengan berbagai permasalahan tersebut membuat perkembangan UMKM menjadi terbatas dan sulit bersaing dengan usaha asing.

Salah satu permasalahan inti dari UMKM khususnya usaha mikro adalah terbatasnya modal yang disebabkan belum unbankable. Oleh karena itu perlu adanya lembaga keuangan mikro (LKM) untuk membantu permodalan dari usaha mikro tersebut. Zeller dan Meyer (2002) mengklasifikasikan indikator kinerja LKM dalam tiga kategori, yaitu kesinambungan keuangan (Financial Sustainability), keterjangkauan LKM (Outreach), dan dampak keberadaan BMT dalam sebuah lingkungan (Impact) yang kemudian disebut sebagai segitiga keuangan mikro (The Triangle of Microfinance) Lembaga kevangan mikro dalam memperluas outreach-nya terhadap UMKM, ditentukan oleh kemampuan lembaga tersebut 
Riyadi, et al/Jurnal Ekonomi Syariah Teori dan Terapan Vol. 6 No. 5 Mei 2019: 1082-1096; PENGARUH LEMBAGA KEUANGAN MIKRO SYARIAH (LKMS) BERKUALITAS TERHADAP PENINGKATAN KEUNTUNGAN USAHA MIKRO KOTA DEPOK

dalam menjaga financial sustainability, sehingga lembaga keuangan tersebut mempunyai positive multiplier effect terhadap perkembangan perekonomian mulai dari sekitar lingkungan lembaga keuangan tersebut hingga lingkungan nasional. Ketiga macam indikator ini saling berkaitan satu sama lain sehingga untuk dapat mengatakan "perform", LKM harus dapat memenuhi ketiga indikator tersebut (Septiana 2014).

Upaya yang dapat dilakukan untuk memperkuat LKM agar LKM dapat menjangkau secara luas, menjaga kesinambungan keuangan dan memberikan dampak positif adalah dengan cara: (1) memperkuat permodalan dan manajemen lembaga kevangan masyarakat, (2) penggalangan dukungan dan fasilitasi pembiayaan UMKM dengan lembaga keuangan, (3) penggalangan partisipasi berbagai pihak dalam pembiayaan UMKM, (4) optimalisasi pendayagunaan potensi pembiayaan UMKM di daerah, (5) peningkatan capacity building LKM, (6) pelatihan bagi pengelola LKM untuk meningkatkan kapasitas pengelola LKM, (7) serta adanya lembaga penjamin untuk menjamin kredit LKM dan tabungan nasabah LKM (Soetrisno 2012). Dengan melakukan berbagai upaya tersebut akan membuat LKM dapat menjalankan kinerjanya secara efektif dan efisien.

Baitul maal wat tamwil (BMT) merupakan salah satu contoh dari lembaga keuangan mikro syariah (LKMS) yang dikenal masyarakat Indonesia.
Keberadaan BMT di Indonesia berpotensi besar untuk mengatasi masalah permodalan yang dimiliki Usaha Mikro. Hal tersebut mengingat layanan keuangan mikro syariah BMT relatif dapat lebih mudah diakses sebagian besar usaha mikro yang unbankable. Pembiayaan syariah memberikan kelebihan yang tidak dimiliki oleh lembaga konvensional karena tidak adanya sistem bunga yang dapat membebani UMKM (beban bunga yang terus bertambah)(Anggraeni et al. 2013) Dalam ketiga kategori tersebut LKMS dalam hal ini BMT harus bisa memberikan impact langsung kepada usaha mikro yang ada di lingkungan sekitarnya, salah satunya melalui program pembiayaan untuk mengatasi permasalahan usaha mikro yang masih unbankable. MenurutEffendi and Utami (2016)BMT bisa menjadi alternatif untuk usaha mikro dan kecil (UMK) karena persyaratan yang diberikan untuk mengajukan pembiayaan lebih mudah dari lembaga keuangan formal lainnya.

Berdasarkan permasalahan di atas, beberapa pertanyaan yang akan di jawab dalam penelitian ini adalah :

1. Bagaimana karakteristik usaha mikro yang menjadi anggota LKMS berkualitas dan sehat di kota Depok?

2. Bagaimana pengaruh LKMS berkualitas dan sehat terhadap peningkatan keuntungan usaha mikro kota Depok?

3. Apa saja faktor-faktor yang mempengaruhi peningkatan keuntungan usaha mikro yang 
Riyadi, et al/Jurnal Ekonomi Syariah Teori dan Terapan Vol. 6 No. 5 Mei 2019: 1082-1096; PENGARUH LEMBAGA KEUANGAN MIKRO SYARIAH (LKMS) BERKUALITAS TERHADAP PENINGKATAN KEUNTUNGAN USAHA MIKRO KOTA DEPOK

menjadi anggota dari LKMS

berkualitas dan sehat kota Depok?

\section{TINJAUAN PUSTAKA}

\section{Baitul Maal Wat Tamwil}

Sudarsono (2003) menjelaskan

Baitul Maal Wat Tamwil (BMT) terdiri dari dua istilah yaitu Baitul almaal dan Baitul tamwil. Baitul maal lebih pada usahausaha pengumpulan dana non profit seperti zakat, infaq dan sodaqoh. Sedangkan Baitul Tamwil sebagai usaha pengumpulan dan penyualuran dana komirsiil. Usaha tersebut tidak bisa dipisahkan dari BMT sebagai usaha pendukung pada kegiatan ekonomi masyarakat. Peran umum BMT dalah melakukan pembinaan dan pendanaan yang berdasarkan sistem syariah. Yang menegaskan prinsip syariah dalam kehidupan ekonomi masyarakat, sebagai lembaga keuangan yang bersentuhan langsung dengan kehidupan masyarakat kecil yang serba cukup ilmu pengetahuan dan materi (Sudarsono 2003).

\section{Usaha Mikro}

Di Indonesia, definisi Usaha Mikro diatur dalam dalam Undang-Undang Republik Indonesia Nomor 20 Tahun 2008 tentang UMKM. Dalam Bab I (Ketentuan Umum), Pasal 1 dari UU tersebut, dinyatakan bahwa usaha mikro adalah usaha produktif milik orang perorangan dan/atau badan usaha perorangan yang memenuhi kriteria usaha mikro sebagaimana diatur dalam UU tersebut. Kriteria yang digunakan untuk mendefinisikan Usaha Mikro seperti yang tercantum dalam Undang-Undang
Republik Indonesia Nomor 20 Tahun 2008 adalah nilai kekayaan bersih atau nilai aset tidak termasuk tanah dan bangunan tempat usaha, atau hasil penjualan tahunan. Dengan kriteria ini, menurut UU itu, usaha mikro adalah unit usaha yang memiliki nilai aset paling banyak Rp 50 juta atau dengan hasil penjualan tahunan paling besar Rp 300 juta.

Menurut Keputusan Menteri Keuangan No.40/KMK.06/2003, usaha mikro usaha produktif milik keluarga atau perorangan Warga Negara Indonesia dan memiliki hasil penjualan paling banyak Rp 100000000.00 per tahun. Usaha mikro dapat mengajukan kredit kepada bank paling banyak Rp 50000 000.00. Menurut Fahrudin (2012) Mayoritas usaha mikro berada pada sektor informal dan tidak terdaftar. Hal tersebut menyebabkan kurangnya kepercayaan lembaga kevangan formal dalam memberikan permodalan. Karakteristik Usaha Mikro yang menonjol di antaranya pendidikan yang rendah oleh pelaku usaha mikro dan biasanya hasil produksi ditujukan untuk kelompok berpendapatan rendah (Gina and Effendi 2014).

\section{Pembiayaan Syariah}

Pembiayaan berdasarkan prinsip syariah seperti yang dijelaskan dalam Undang -Undang Republik Indonesia Nomor 10 Tahun 1998 adalah penyediaan vang atau tagihan yang dipersamakan dengan itu berdasarkan persetujuan atau kesepakatan antara bank dengan pihak lain yang mewajibkan pihak yang dibiayai untuk mengembalikan uang atau tagihan 
Riyadi, et al/Jurnal Ekonomi Syariah Teori dan Terapan Vol. 6 No. 5 Mei 2019: 1082-1096; PENGARUH LEMBAGA KEUANGAN MIKRO SYARIAH (LKMS) BERKUALITAS TERHADAP PENINGKATAN KEUNTUNGAN USAHA MIKRO KOTA DEPOK

tersebut setelah jangka waktu tertentu dengan imbalan atau bagi hasil. Prinsip Syariah adalah aturan perjanjian berdasarkan hukum Islam antara bank dan pihak lain untuk penyimpanan dana dan atau pembiayaan kegiatan usaha, atau kegiatan lainnya yang dinyatakan sesuai dengan syariah.

Pembiayaan syariah yang erat dengan prinsip bagi hasilnya yang membedakan dengan pembiayaan berprinsip bunga. Menurut Antonio (2001) hal yang membedakan bunga dengan bagi hasil yang pertama yaitu penentuan bunga pada waktu akad dengan asumsi selalu untung sedangkan pada bagi hasil besarnya nisab memperhitungkan untung rugi. Kedua, besarnya bunga tergantung pada modal yang dipinjamkan sedangkan rasio bagi hasil tergantung pada jumlah keuntungan yang diperoleh. Ketiga, pembayaran bunga tanpa memperhatikan apakah usaha yang dijalankan nasabah untung atau rugi sedangkan bagi hasil bergantung pada keuntungan dan kerugian ditanggung bersama. Keempat, jumlah pembayaran bunga tidak meningkat ketika jumlah keuntungan meningkat sedangkan pada bagi hasil pembagian laba sesuai dengan peningkatan jumlah pendapatan. Kelima, sistem bunga diragukan oleh semua agama termasuk Islam sedangkan pada sistem bagi hasil tidak ada yang meragukannya.

\section{Penelitian Terdahulu}

Penelitian yang dilakukan olehGina and Effendi (2014) tentang Program
Pembiayaan Lembaga Keuangan Mikro Syariah (LKMS) dalam Peningkatan Kesejahteraan Pelaku Usaha Mikro (Studi Kasus BMT Baitul Karim Bekasi). Menggunakan analisis deskriptif, analisis logistik dan model Ordinary Least Square (OLS). Penelitian menunjukan Jumlah pembiayaan yang diambil responden berpengaruh positif dan signifikan terhadap peningkatan pendapatan pelaku usaha mikro dengan didukung oleh variabel-variabel lain seperti jumlah anggota keluarga yang memiliki penghasilan, tingkat pendidikan, dan variabel etka dan moral nasabah.Jumlah pembiayaan yang diambil responden berpengaruh signifikan pada kesejahteraan berdasarkan opini responden dengan didukung oleh variabel lain seperti lamanya menjadi anggota BMT, pengeluaran makan, dan pendapatan responden.

Anggraeni et al. (2013) meneliti tentang Akses UMKM Terhadap Pembiayaan Mikro Syariah dan Dampaknya Terhadap Perkembangan Usaha : Kasus BMT Tadbiirul Ummah, Kabupaten Bogor. Penelitian dilakukan dengan Metode Regresi Logistik dan Metode Regresi Linier Berganda. Hasil penelitian menunjukan Akses UMKM BMT terhadap perbankan jauh lebih kecil dibandingkan responden kontrol. Faktorfaktor yang mempengaruhi akses UMKM terhadap pembiayaan mikro syariah dari BMT adalah variabel dummy akses simpanan, umur pengusaha UMKM, dummy jenis usaha 2 (manufaktur), serta 
Riyadi, et al/Jurnal Ekonomi Syariah Teori dan Terapan Vol. 6 No. 5 Mei 2019: 1082-1096; PENGARUH LEMBAGA KEUANGAN MIKRO SYARIAH (LKMS) BERKUALITAS TERHADAP PENINGKATAN KEUNTUNGAN USAHA MIKRO KOTA DEPOK

omset usaha. Berdasarkan analisis OLS, faktor-faktor yang mempengaruhi nilai perkembangan keuntungan usaha UMKM adalah lama pendidikan, lama usaha, besarnya pembiayaan syariah BMT dan besarnya kredit konvensional.

Syafitri (2010) yang meneliti tentang Analisis Strategi Pemasaran Produk Dana Koperasi Baitul Maal Wa Tamwil Muamalat Di Perumnas Bantarjati Bogor Utara. Metode yang digunakan adalah Data yang digunakan dalam penelitian ini terdiri dari data primer dan sekunder. Menggunakan metode wawancara langsung dengan pengurus Koperasi dan penyebaran kuesioner kepada pengurus koperasi. Hasil penelitian menunjukan Faktor internal yang menjadi kekuatan Koperasi Muamalat adalah Memiliki integritas terhadap prinsip muamalah dan komitmen kuat untuk membantu perekonomian umat, Ada petugas khusus yang melakukan pemungutan simpanan setiap hari, Jangkauannya mencapai pelosok, Berbasis syariah dan bebas dari unsur riba, serta Jalinan rasa kekeluargaan dan kedekatan dengan komunitas setempat. Sedangkan faktor eksternal yang menjadi kelemahan adalah Dana relatif terbatas, Kegiatan promosi masih kurang, sehingga belum dikenal luas oleh masyarakat, sering berpindah-pindah tempat, Lokasi kurang strategik dan Lemahnya sosialisasi yang dilakukan Koperasi BMT Muamalat mengenai kegiatan yang dilakukannya.
Nabilah (2015) tentang Analisis

Risiko Dan Faktor-Faktor Yang Memengaruhi Tingkat Pengembalian Pembiayaan Syariah Pada Sektor Pertanian ( Studi Kasus Bmt As Salam, Kramat, Demak. Metode studi kasus melalui observasi dan wawancara kepada pihak pengurus BMT As Salam dan nasabah pembiayaan dengan menggunakan kuisioner. Pengambilan sampel dilakukan dengan teknik pengambilan purposive sampling. Hasil identifikasi risiko pembiayaan dan operasional di BMT As Salam menunjukan risiko yang memiliki probabilitas dan dampak yang paling tinggi adalah risiko kurangnya pengetahuan nasabah dalam akad syariah yang digunakan serta nasabah terlambat mengembalikan pembiayaan. Risiko-risiko pembiayaan sektor pertanian di BMT As Salam masih berada pada tingkat medium risk, dimana risiko tersebut masih dapat dikendalikan oleh BMT As Salam.

\section{METODE PENELITIAN}

\section{Jenis dan Sumber Data}

Jenis data yang digunakan dalam penelitian ini adalah data primer dan sekunder. Data primer diperoleh dari hasil wawancara kuisioner dengan para pelaku Usaha Mikro yang mendapatkan pembiayaan dari 3 Lembaga Keuangan Mikro Syariah (LKMS) di Kota DepoK. sedangkan data sekunder diperoleh dari Kementrian Koperasi dan UMKM, Badan Pusat Statistik (BPS), Dinas Pemerintah Kota Depok, dokumen dan laporan keuangan 
Riyadi, et al/Jurnal Ekonomi Syariah Teori dan Terapan Vol. 6 No. 5 Mei 2019: 1082-1096; PENGARUH LEMBAGA KEUANGAN MIKRO SYARIAH (LKMS) BERKUALITAS TERHADAP PENINGKATAN KEUNTUNGAN USAHA MIKRO KOTA DEPOK

LKMS yang diteliti, buku, jurnal, skripsi, tesis dan internet.

\section{Lokasi dan Waktu Penelitian}

Penelitian ini dilakukan di 3 LKMS yang ada di Kota Depok yang masuk ke dalam kategori berkualitas dan sehat, yaitu KSU Syariah Huwaiza, KJKS Berkah Mandiri dan Koperasi Bina Usaha Sejahtera. Penentuan lokasi dilakukan secara purposive (sengaja) dengan melihat banyaknya LKMS yang ada di Kota Depok dan karakter masyarakat Depok yang terkenal religius. Penelitian ini dilakukan pada bulan Februari-Maret 2018.

\section{Metode Pengumpulan Data}

Pengumpulan data dalam penelitian ini menggunakan metode wawancara kepada para nasabah pembiayaan yang mempunyai usaha Mikro dengan media kuisioner. Pemilihan sampel dilakukan dengan menggunakan metode convenience sampling yaitu prosedur mengambil sampel yang sesuai dengan ketentuan atau persyaratan sampel dari populasi tertentu yang paling mudah dijangkau dan didapatkan. Sampel yang diambil dalam penelitian ini sebanyak 60 responden penerima pembiayaan dari nasabah yang memperoleh pembiayaan di 3 BMT Kota Depok, yang masing-masing BMT diambil 20 responden.

\section{Metode Pengolahan dan Analisis Data}

Pada penelitian ini, metode analisis yang digunakan adalah metode analisis deskriptif, analisis uji beda menggunakan Eviews, dan Ordinary Least Square (OLS).
Analisis deskriptif digunakan untuk mendeskripsikan data yang diperoleh dari hasil penelitian agar informasi dapat lebih mudah dipahami. Analisis uji beda digunakan untuk menyajikan data pengujian hipotesis serta Ordinary Least Square (OLS) digunakan untuk menyajikan data pengukur. Data yang digunakan dalam penelitian ini adalah data primer hasil wawancara dengan pelaku usaha mikro.

\section{Metode Ordinary Least Square (OLS)}

Metode kuadrat terkecil biasa Ordinary Least Square (OLS) digunakan dalam menganalisis regresi linier berganda yakni regresi dimana lebih dari satu variabel penjelas atau variabel bebas.Metode ini digunakan untuk menjelaskan perilaku variabel tak bebas, dalam hal ini yaitu untuk mengidentifikasi faktor-faktor dampak pembiayaan yang memengaruhi perubahan produktivitas usaha mikro. Metode OLS memiliki beberapa sifat teoritis yang kokoh, yang diringkaskan dalam teorema GaussMarkov, yaitu berdasarkan asumsi-asumsi dari model regresi linear klasik. Penaksir OLS memiliki varian yang terendah di antara penaksir-penaksir linier lainnya, dalam hal ini, penaksir OLS disebut sebagai penaksir tak bias linier terbaik (Best Linear Unbiased Estimators / BLUE) (Gujarati 2006).

Model OLS yang digunakan untuk mengidentifikasi faktor-faktor dampak pembiayaan yang memengaruhi omset Usaha Mikro yaitu: 
Riyadi, et al/Jurnal Ekonomi Syariah Teori dan Terapan Vol. 6 No. 5 Mei 2019: 1082-1096; PENGARUH LEMBAGA KEUANGAN MIKRO SYARIAH (LKMS) BERKUALITAS TERHADAP PENINGKATAN KEUNTUNGAN USAHA MIKRO KOTA DEPOK

$\operatorname{Ln} Y i=\beta 0+\beta 1 \operatorname{Ln} X 1+\beta 2 \operatorname{Ln} X 2+B 3 \operatorname{Ln} X 3+$ $B 4 \operatorname{Ln} X 4+\beta 5 \operatorname{Ln} X 5+\beta 6 \operatorname{Ln} D 2+\beta 7 \operatorname{Ln} D 3$

Keterangan :

Ln Yi $=$ Produktivitas

$\beta o=$ Parameter

$\mathrm{X} 1=\mathrm{Umur}$

$\mathrm{X} 2$ = Lama Usaha

X3 = Frekuensi Pembiayaan

X4 = Omzet Usaha

X5 = Tenaga Kerja

Dl = Dummy pendidikan $(1=$ ikut wajib belajar 9 tahun, 0 = tidak ikut wajib belajar 9 tahun)

D2 = Dummy status usaha 1 = usaha utama, 0 = usaha sampingan)

\section{HASIL DAN PEMBAHASAN}

\section{Gambaran Umum}

Berdasarkan data Dinas Koperasi, UMKM dan Pasar Depok pada tahun 2017 ada 33 LKMS berbadan hukum koperasi yang aktif. Dari jumlah tersebut diambil 3 LKMS yang diteliti, yaitu Koperasi Syariah BUSRA (Bina Usaha Sejahtera), KSU Syariah Huwaizah dan KJKS BMT Berkah Madani. Pemilihan ketiga LKMS tersebut didasarkan karakteristiknya yang sama, dari awal berdiri Huwaiza dan Berkah Madani sudah berdiri sejak tahun 2005, sedangkan Busra berdiri satu tahun kemudian pada 2006. Ketiganya juga termasuk kedalam kategori koperasi yang berkualitas dan sehat menurut penilaian dari Dinas Koperasi, UMKM dan Pasar Kota Depok. Selain itu ketiganya juga mewakili wilayah kecamatan yang berbeda. Huwaiza berada di kecamatan Limo atau Depok bagian Barat, sedangkan Busra berada di Kecamatan Pancoran Mas atau Depok bagian tengah dan Berkah Madani berada di Kecamatan Cimanggis atau Depok bagain timur.

Dalam hal Pembiayaan ketiganya memiliki produk pembiayaan yang mirip, Busra memiliki produk pembiayaan murabahah, Rahn dan Qardhul Hasan. Sedangkan Huwaiza memiliki produk pembiayaan Murabahah, ljarah dan Qardhul Hasan. Dan Berkah Madani memiliki produk pembiayaan Murabahah, Mudharabah, Musyarakah dan ljarah. Untuk total aset pembiayaan terbesar dimiliki oleh Berkah Madani dengan nilai $5,134,491,818$ disusul oleh Busra dan Huwaiza Berdasarkan hasil observasi ketiga LKMS ini memberikan kemudahan anggotanya untuk melakukan pembiayaan, seperti persyaratan mengajukan pembiayaan yang mudah dan cepat, tidak sampai satu pekan pembiayaan yang diajukan bisa langsung cair sesuai dengan prinsip syariah. Lalu kemudahan lainnya adalah dalam hal pembayaran pembiayaan bisa diambil langsung ke rumah-rumah, sehingga akan memudahkan anggotanya untuk membayar cicilan tepat waktu tanpa harus meninggalkan usahanya.

\section{Karakteristik Responden}

Dalam penelitian yang telah dilakukan jumlah nasabah berdasarkan jenis terdiri atas 25 orang laki-laki dan 35 orang perempuan. Hal ini menjadi bukti bahwa LKMS khususnya BMT lebih fokus memberdayakan perempuan untuk memiliki ataupun memperbesar usaha yang dimiliki.Selain itu ada sekitar 3,3\% 
Riyadi, et al/Jurnal Ekonomi Syariah Teori dan Terapan Vol. 6 No. 5 Mei 2019: 1082-1096; PENGARUH LEMBAGA KEUANGAN MIKRO SYARIAH (LKMS) BERKUALITAS TERHADAP PENINGKATAN KEUNTUNGAN USAHA MIKRO KOTA DEPOK

nasabah yang beragama kristen ikut menjadi anggota dan melakukan pembiayaan di ketiga LKMS yang diteliti. Responden dalam penelitian ini memiliki tingkat pendidikan yang beragam. Tingkat pendidikan responden yang paling banyak adalah SMA dengan persentase $53,3 \%$, kemudian adalah SD dengan persentase $25 \%$, dilanjutkan dengan persentase tingkat pendidikan SMP sebesar $15 \%$ dan responden paling sedikit berasal dari Perguruan Tinggi.Ratarata umur yang menjadi responden dari penelitian ini adalah 45 tahun, dengan minimal umur responden 24 tahun dan maksimal 60 tahun.

Mayoritas jenis usaha dari responden adalah perdangan, ada sekitar 42 atau $70 \%$ dari responden memiliki usaha sebagai pedagang. Sedangkan sisanya 16 responden memiliki usaha jasa dan 2 lainnya memiliki usaha pertanian dan produksi.Mayoritas responden menjadikan usahanya sebagai usaha sampingan. Tercatat ada $58,3 \%$ atau 35 responden yang statususahanya merupakan usaha sampingan. Sedangan $41,7 \%$ atau 25 responden lainnya menjadikan usahanya sebagai usaha utama.

\section{Dampak Pembiayaan Terhadap}

\section{Keuntungan Usaha Mikro}

Program pembiayaan untuk Usaha Mikro dari ketiga LKMS yang diteliti bertujuan untuk meningkatan dan mengembangkan Usaha Mikro yang ada di Depok supaya pemilik Usaha Mikro bisa sejahtera. Dalam penelitian ini, perkembangan usaha bisa dilihat dalam perkembangan keuntungan yang didapatkan setelah melakukan pembiayaan. Dari 60 responden pelaku Usaha Mikro yang di wawancarai ada $85 \%$ usaha yang mengalami peningkatan omset, sedangkan 15\% lainnya tidak mengalami peningkatan keuntungan.Berdasarkan hasil penelitian yang dilakukan kepada responden, dampak pembiayaan LKMS berhasil meningkatkan keuntungan Usaha Mikro sebesar 2,604 juta atau meningkat dengan persentase $68,5 \%$.

\section{Faktor-Faktor yang Mempengaruhi Keuntungan Usaha Mikro}

Pembiayaan yang diberikan oleh LKMS kepada Usaha Mikro diharapkan memberikan dampak positif untuk mengembangkan usahanya. Analisis pengaruh pembiayaan yang dilakukan LKMS terhadap perkembangan Usaha Mikro menggunakan metode Ordinary Least Square. Hasil dari metode OLS yang disajikan dalam tabel. menunjukkan nilai $R$-square sebesar 56.22 yang artinya $56.22 \%$ keragaman nilai perkembangan usaha UMKM berdasarkan nilai perkembangan omset dapat dijelaskan oleh masing-masing variabel penjelas dalam model, sisanya dijelaskan oleh variabel lain.

Hasil uji F-statistik diperoleh nilai probabilitas F-statistik 0.000001 . Karena nilai F-statistik yang diperoleh lebih kecil dari taraf nyata 5\%, maka dapat disimpulkan bahwa terdapat minimal satu dari variabel dummy pendidikan, dummy 
Riyadi, et al/Jurnal Ekonomi Syariah Teori dan Terapan Vol. 6 No. 5 Mei 2019: 1082-1096; PENGARUH LEMBAGA KEUANGAN MIKRO SYARIAH (LKMS) BERKUALITAS TERHADAP PENINGKATAN KEUNTUNGAN USAHA MIKRO KOTA DEPOK

status usaha, frekuensi pembiayaan, lama anggota, lama usaha, omzet, tenaga kerja dan umur yang mempengaruhi pendapatan UMKM setelah mendapatkan pembiayaan usaha.

Hasil uji $\dagger$ dapat dilihat pada nilai probabilitas † hitung. Jika nilai probabilitas † hitung lebih kecil dari tingkat kesalahan $10 \%$ maka dapat disimpulkan bahwa variabel bebas berpengaruh signifikan terhadap variabel tidak bebasnya, sedangkan apabila nilai probabilitas $\dagger$ hitung lebih besar dari tingkat kesalahan $10 \%$ maka variabel bebas tidak berpengaruh signifikan terhadap variabel tidak bebasnya. Hasil estimasi probabilitas † hitung pada Tabel 18 menunjukkan variabel lama anggota, frekuensi pembiayaan, omzet, tenaga kerja dan umur memiliki nilai probabilitas yang lebih kecil dari taraf nyata 10\%, maka dapat disimpulkan variabel lama anggota, frekuensi pembiayaan, omzet, tenaga kerja dan umur berpengaruh signifikan terhadap peningkatan keuntungan Usaha Mikro setelah mengikuti pembiayaan dari LKMS di Kota Depok.

Sedangkan hasil estimasi nilai probabilitas $t$ hitung variabel dummy pendidikan, dummy status usaha, dan lama usaha memiliki nilai probabilitas yang lebih besar dari taraf nyata $10 \%$, maka dapat disimpulkan variabel umur, modal pertama, jumlah pembiayaan terakhir, dan lama menjadi anggota tidak berpengaruh secara signifikan terhadap peningkatan keuntungan Usaha Mikro setelah mengikuti pembiayaan dari LKMS di Kota Depok.

Tabel 1.

Faktor-Faktor yang Mempengaruhi

Peningkatan Keuntungan Usaha Mikro

\begin{tabular}{lcc} 
Variabel & Koefisien & Probabilitas \\
\hline Konstantan & 11.26624 & 0.0000 \\
Pendidikan & -0.20005 & 0.1950 \\
Status Usaha & -0.19520 & 0.2241 \\
Frekuensi & -0.24728 & $0.0535^{* *}$ \\
Pembiayaan & 0.35809 & $0.0006^{*}$ \\
Lama Anggota & -0.13129 & 0.2983 \\
Lama Usaha & 0.44131 & $0.0000^{*}$ \\
Omzet & 0.24410 & $0.0357^{*}$ \\
Tenaga Kerja & -0.98404 & $0.0181^{*}$ \\
Umur & 0.562186 &
\end{tabular}

R Squere $\quad 0.562186$

Prob (F Statistik) 0.000001

*signifikan pada taraf nyata $5 \%$

*signifikan pada taraf nyata $10 \%$

Variabel frekuensi pembiayaan berpengaruh negatif terhadap peningkatan keuntungan responden usaha mikro dengan koefisien sebesar 0.24728 dan signifikan pada taraf nyata $10 \%$ yang berarti peningkatan frekuensi pembiayaan $1 \%$ akan mengurangi tingkat keuntungan sebesar $0.247 \%$. Ini berarti semakin sering responden melakukan pembiayaan akan menurunkan tingkat keuntungan usahanya. Hal ini sesuai dengan penelitian Puspitasari (2012) yang menyatakan bahwa frekuensi pembiayaan berpengaruh secara negatif terhadap peningkatan keuntungan usaha. Dari penelitian di lapangan hanya 23.3\% responden yang benar-benar paham terhadap akad yang ia gunakan 
Riyadi, et al/Jurnal Ekonomi Syariah Teori dan Terapan Vol. 6 No. 5 Mei 2019: 1082-1096; PENGARUH LEMBAGA KEUANGAN MIKRO SYARIAH (LKMS) BERKUALITAS TERHADAP PENINGKATAN KEUNTUNGAN USAHA MIKRO KOTA DEPOK

dalam proses pembiayaannya, sedangkan sisanya hanya paham sebagian dan kebanyakan tidak paham sama sekali terhadap akad yang ia gunakan. Hal ini menimbulkan moral hazard dalam penggunaan pembiayaan yang diberikan oleh LKMS, sehingga pembiayaan yang seharusnya digunakan untuk membantu permodalan usahanya justru digunakan untuk konsumsi pribadi maupun keluarganya.

$\begin{array}{lll}\text { Variabel } & \text { lama } & \text { anggota } \\ \text { berpengaruh } & \text { positif } & \text { terhadap }\end{array}$
keuntungan responden dengan koefisien sebesar 0.35809 dengan signifikan pada taraf nyata $10 \%$. Berdasarkan hasil tersebut menunjukan semakin lama pemilik usaha mikro menjadi anggota LKMS sebesar $1 \%$ akan meningkatkan keuntungan usahanya sebesar $0.358 \%$. Hasil ini membuktikan bahwa keuntungan usaha dari responden akan semakin meningkat jika semakin lama menjadi anggota dari LKMS. Hasil ini sesuai dengan penelitian yang dilakukan oleh Fauzi (2018) yang menyatakan bahwa semakin lama pemilik usaha menjadi anggota LKMS, maka akan semakin mudah memperoleh akses pembiayaan sehingga akan meningkatkan keuntungan usahanya. Berdasarkan pengamatan langsung masing-masing LKMS memberikan berbagai program yang menunjang perkembangan usaha anggotanya, mulai dari program pembiayaan untuk membantu anggotanya yang mengalami kekurangan modal, lalu program jemput tabungan yang memudahkan anggota menyimpan sisa keuntungan secara rutin, sampai pelatihan serta pengajian rutin yang meningkatkan softskill dan kesadaran anggotanya dalam berwirausaha.

Variabel omzet berpengaruh positif terhadap peningkatan keuntungan responden dengan koefisien sebesar 0.441 dan signifikan pada taraf nyata $10 \%$. Berdasarkan penelitian tersebut menunjukan peningkatan omzet sebesar 1\% akan meningkatkan keuntungan sebesar $0.441 \%$. Hal ini membuktikan semakin besarnya omzet yang dihasilkan responden akan meningkatkan keuntungan usahanya. Tunas (2014) mengatakan Besarnya omset usaha menunjukkan besarnya usaha yang dijalankan pelaku UMKM sehingga memiliki kemampuan lebih untuk membayar pengembalian pinjaman. Dari penelitian yang dilakukan, usaha mikro yang lebih berani untuk meningkatkan modal usaha untuk meningkatkan omzetnya memiliki peningkatan keuntungan yang lebih besar dibandingkan usaha mikro lainnya. Hasil ini juga sesuai dengan penelitian Puspitasari (2012) yang menyatakan bahwa variabel omzet berpengaruh positif terhadap peningkatan keuntungan usaha.

Variabel tenaga kerja berpengaruh positif terhadap peningkatan keuntungan responden dengan koefisien 0.244 dan signifikan pada taraf nyata $10 \%$. Berdasarkan hasil 
Riyadi, et al/Jurnal Ekonomi Syariah Teori dan Terapan Vol. 6 No. 5 Mei 2019: 1082-1096; PENGARUH LEMBAGA KEUANGAN MIKRO SYARIAH (LKMS) BERKUALITAS TERHADAP PENINGKATAN KEUNTUNGAN USAHA MIKRO KOTA DEPOK

tersebut, artinya peningkatan tenaga kerja $1 \%$ akan meningkatkan keuntungan sebesar $0.244 \%$. Hasil ini sejalan dengan Antara dan Aswitari (2016) yang menyatakan bahwa tenaga kerja berpengaruh positif terhadap peningkatan usaha di Denpasar Barat. Hasil ini menunjukan dengan semakin banyak tenaga kerja yang dimiliki responden akan meningkatkan keuntungan usahanya. Berdasarkan penelitian yang dilakukan usaha yang memiliki tenaga kerja lebih banyak memiliki tingkat produktivitas yang lebih besar dibandingkan usaha pesaingnya yang sejenis. Hal ini sejalan dengan penelitian yang dilakukan oleh Putri dan Kesumajaya (2017) yang menyatakan bahwa bahwa penyerapan tenaga kerja berpengaruh positif dan signifikan terhadap produksi, dimana jika jumlah produksi lebih besar akan menyebabkan meningkatnya kebutuhan akan tenaga kerja pada industri tersebut.

Variabel umur berpengaruh
negatif terhadap peningkatan keuntungan responden dengan koefisien -0.984 dan signifikan pada taraf nyata 10\%. Berdasarkan hasil tersebut menunjukan peningkatan umur responden sebesar 1\% akan mengurangi keuntungan sebesar $0.984 \%$. Hasil ini menunjukan dengan semakin mudanya umur responden akan semakin meningkatkan keuntungan usaha yang dimiliki Hasil ini sesuai dengan penelitian Mayoli (2017) yang menunjukan bahwa umur berpengaruh negatif kepada peningkatan keuntungan usaha. Berdasarkan hasil pengamatan langsung terhadap responden menunjukan bahwa dengan semakin tuanya umur responden justru akan membuat responden menurun kinerja dan inovasinya dalam mengembangkan usaha yang ia punya. Hasil ini sesuai dengan penelitian yang dilakukan oleh Damayanti (2013) yang menyatakan bahwa kemampuan kerja seorang akan bertambah sampai pada tingkat umur tertentu, kemudian akan menurun. Semakin tua umur seseorang, kemampuan kerja relatif menurun.

\section{v. SIMPULAN DAN SARAN}

\section{Simpulan}

Berdasarkan penelitian yang dilakukan, maka didapatkan kesimpulan sebagai berikut:

1. Karakteristik usaha mikro yang menjadi anggota dari LKMS Kota Depok terbagi menjadi tiga bagian. Pertama untuk karakteristik responden mayoritas merupakan perempuan, beragama Islam dan berpendidikan terakhir SMA. Kedua untuk karakteristik usaha mayoritas memiliki usaha di bidang perdagangan dengan mayoritas menjadikan usahanya menjadi usaha sampingan. Untuk karakteristik pembiayaan rata-rata menjadi anggota selama lima tahun dengan frekuensi pembiayaan sebanyak tiga sampai 4 kali dan nilai pembiayaan sebesar 5.8 juta.

2. LKMS memberikan dampak positif untuk peningkatan usaha mikro. Terdapat $85 \%$ responden yang 
Riyadi, et al/Jurnal Ekonomi Syariah Teori dan Terapan Vol. 6 No. 5 Mei 2019: 1082-1096; PENGARUH LEMBAGA KEUANGAN MIKRO SYARIAH (LKMS) BERKUALITAS TERHADAP PENINGKATAN KEUNTUNGAN USAHA MIKRO KOTA DEPOK

meningkat keuntungan usahanya setelah menjadi anggota LKMS dengan rata-rata penigkatan usaha sebesar 2.604 juta.

3. Ada beberapa faktor yang mempengaruhi peningkatan keuntungan usaha mikro yang menjadi anggota di LKMS. Lama anggota, omzet dan tenaga kerja adalah variabel yang berpengaruh positif dan signifikan. Frekuensi pembiayaan dan umur menjadi variabel yang berpengaruh negatif dan signifikan terhadap peningkatan keuntungan usaha mikro.

\section{Saran}

Berdasarkan penelitian yang dilakukan, maka terdapat saran sebagai berikut:

1. LKMS diharapkan bisa lebih memberikan kesempatan usaha bagi perempuan yang terdapat dalam pengajian rutin lingkungannya supaya bisa lebih produktif dan membantu perekonomian keluarganya.

2. Diharapkan Dinas Koperasi dan UMKM Pasar kota Depok lebih membangun LKMS untuk menjadi LKMS yang berkualitas dan sehat. Hal ini untuk membantu perkembangan usaha mikro di kota Depok, sehingga nantinya dapat meningkatkan kesejahteraan masyarakat kota Depok

3. LKMS diharapkan bisa memperhatikan variabel lama anggota, omzet usaha, tenaga kerja, frekuensi pembiayaan dan umur dalam memberikan pembiayaan kepada usaha mikro.

\section{DAFTAR PUSTAKA}

Anggraeni, Lukytawati, Herdiana Puspitasari, Salahuddin El Ayubbi, and Ranti Wiliasih. 2013. "Akses UMKM Terhadap Pembiayaan Mikro Syariah Dan Dampaknya Terhadap Perkembangan Usaha: Kasus BMT Tadbiirul Ummah , Kabupaten Bogor The Access of MSME towards Islamic Microfinancing and Its Impact on Business Development: A Case of BMT Tadbiirul Ummah , Bogor." I(1): 56-67.

Antonio MS. 2001. Bank Syariah dari Teori ke Praktek. Jakarta (ID): Gema Insani

Apriadi F, Alexandi MF. 2013. Solusi Peningkatan Sumberdaya Manusia Pada Baytul Maal wat Tamwil (BMT) di Indonesia Melalui Pendekatan Analytic Network Process (ANP). Jurnal alMuzara'ah, Vol. I No. 2, 2013

Antara I, Aswitari L. 2016. Beberapa Faktor Yang Mempengaruhi Pendapatan Pedagang Kaki Lima Di Kecamatan Denpasar Barat. EJurnal Ekonomi Pembangunan Universitas Udayana, Vol. 5 No. 11, 2016.

Beik, I. Arsyianti, L. D., 2016. Ekonomi Pembangunan Syariah (Edisi Revisi). Jakarta (ID): PT Raja Grafindo Persada.

Dani F. 2017. Muhammad Fajar Dani. Analisis Faktor-Faktor yang Mempengaruhi Omset UMKM 
Riyadi, et al/Jurnal Ekonomi Syariah Teori dan Terapan Vol. 6 No. 5 Mei 2019: 1082-1096; PENGARUH LEMBAGA KEUANGAN MIKRO SYARIAH (LKMS) BERKUALITAS TERHADAP PENINGKATAN KEUNTUNGAN USAHA MIKRO KOTA DEPOK

Nasabah Pembiayaan [skripsi] . Bogor (ID): Institut Pertanian Bogor

Fahrudin A. 2012. Pengantar Kesejahteraan. Bandung (ID): PT Rafika Aditama

Firdaus. 2011. Ekonometrika: Suatu Pendekatan Aplikatif. Jakarta (ID): Bumi Aksara

Effendi, Jaenal, and Annisa Rindra Utami. 2016. "THE EFFECT OF SOCIAL CAPITAL ON CUSTOMER ' S." 8(July): 227-42.

Gina, Widya, and Jaenal Effendi. 2014. "Program Pembiayaan Lembaga Keuangan Mikro Syariah ( LKMS ) Dalam Peningkatan Kesejahteraan Pelaku Usaha Mikro ( Studi Kasus BMT Baitul Karim Bekasi ) Financing Program in Microfinance Institution ( LKMS ) of Welfare Enhancing for Micro Business Enterprises ( Study Case in BMT Baitul Karim Bekasi ) 1 Pendahuluan." 3(1): 33-43.

Gujarati DN. Dasar-Dasar Ekonometrika Edisi Kelima. Jakarta (ID):Erlangga.

Guruddin SR. 2014 Peran BMT Dalam Pengembangan Usaha Mikro Kecil (Studi Kasus Pada Bmt Al-Amin Kota Makassar) [skripsi] . Makasar (ID): UIN Alauddin Makassar

Haekal M. 2015. Analisis Tingkat Kesehatan BMT Dan Dampak Pembiayaan Mikro Syariah Terhadap Perkembangan Usaha Mikro (Studi Kasus BMT Al-Azhar Maros) [skripsi] . Bogor (ID): Institut Pertanian Bogor

Hidayati N. 2014. Faktor-Faktor yang Memengaruhi Realisasi
Pembiayaan Mikro Syariah dan Dampaknya terhadap Omzet Usaha Nasabah: Studi Kasus KJKS BMT UGT Sidogiri cabang Koja Jakarta [skripsi] . Bogor (ID): Institut Pertanian Bogor.

Muttaqin A. 2012.Model Pembiayaan Baitul Maal Wa Tamwil Dan Peranannya Dalam Pembinaan Kesejahteraan Usaha Kecil Menengah (UKM). Jurnal Humanity Vol. 7 No. 2, Juli 2012

Nabilah S. 2015. Analisis Risiko dan FaktorFaktor Yang Memengaruhi Tingkat Pengembalian Pembiayaan Syariah Pada Sektor Pertanian ( Studi Kasus BMT As Salam, Kramat, Demak) [skripsi] . Bogor (ID): Institut Pertanian Bogor.

Prastiawati F, Darma ES. 2016. Peran Pembiayaan Baitul Maal Wat Tamwil Terhadap Perkembangan Usaha dan Peningkatan Kesejahteraan Anggotanya dari Sektor Mikro Pedagang Pasar Tradisional. Jurnal Akuntansi dan Investasi. Vol. 17 No. 2, HIm: 197208, Juli 2016

Pristiyanto, Bintoro MH, Soekarto SJ. 2013. Strategi Pengembangan Koperasi Jasa Keuangan Syariah Dalam Pembiayaan Usaha Mikro di Kecamatan Tanjungsari, Sumedang. Jurnal Manajemen IKM. Vol. 8 No.1, Februari 2013

Puspitasari H. 2012. Akses UMKM Terhadap Pembiayaan Mikro Syariah danDampaknya Terhadap 
Riyadi, et al/Jurnal Ekonomi Syariah Teori dan Terapan Vol. 6 No. 5 Mei 2019: 1082-1096; PENGARUH LEMBAGA KEUANGAN MIKRO SYARIAH (LKMS) BERKUALITAS TERHADAP PENINGKATAN KEUNTUNGAN USAHA MIKRO KOTA DEPOK

Perkembangan Usaha (Kasus: BMT Tadbirul Ummah, Kabupaten Bogor). [Skripsi]. Bogor (ID): Institut Pertanian Bogor.

Ridwan M. 2004. Manajemen Baitul Maal Wa Tamwil (BMT). Yogyakarta (ID): UII Press.

Septiana RM. 2013. Analisis Dampak Pembiayaan Mikro Syariah Terhadap Perkembangan Keuntungan UMKM di Kabupaten [skripsi] . Bogor (ID): Institut Pertanian Bogor

Soemitra A. 2009. Bank dan Lembaga Kevangan Syariah. Medan (ID): Kencana.

Soetrisno N. 2012. Lembaga Keuangan Mikro: Energi Pemberdayaan Ekonomi Rakyat. [internet]. [diunduh 2013 Mei 6]. Tersedia pada: http://www.smecda.com.

Sudarno. 2011. Kontribusi Usaha Mikro, Kecil dan Menengah (UMKM) dalam Penyerapan Tenaga Kerja di Depok. Jurnal Ekonomi dan Bisnis. Vol. 10 No.2, Desember 2011

Sudarsono H. 2008. Bank dan Lembaga Keungan Syariah, Deskripsi dan Ilustrasi. Yogyakarta (ID): Ekonisia.

Syafitri N. 2010. Analisis Strategi Pemasaran Produk Dana Koperasi Baitul Maal Wa Tamwil Muamalat Di Perumnas Bantarjati Bogor Utara [skripsi] . Bogor (ID): Institut Pertanian Bogor

Tambunan T. 2009. UMKM di Indonesia. Bogor (ID): Ghalia Indonesia.

Tunas AN. 2014.Analisis Pengaruh Pembiayaan Syariah Terhadap Perkembangan Usaha Mikro Kecil Menengah Di Kota Depok [skripsi] . Bogor (ID): Institut Pertanian Bogor.

Walpole R. 1992. Pengantar Statistika. Jakarta (ID) : Gramedia Pustaka Utama.

Zeller M, Mayer RL. 2002. The Economics of Microfinance. Washington DC (USA): International Food Research Institute. 